\title{
Field Performance of Eucalyptus Hybrids at Planalto da Conquista, Bahia, Brazil
}

\author{
Jamily da Silva Fernandes ${ }^{1}$, Valdemiro Conceição Júnior ${ }^{2}$, \\ Patrícia Anjos Bittencourt Barreto-Garcia ${ }^{3}$ \\ ${ }^{1}$ Universidade Estadual do Sudoeste da Bahia - UESB, Vitória da Conquista/BA, Brasil \\ ${ }^{2}$ Departamento de Fitotecnia, Universidade Estadual do Sudoeste da Bahia - UESB, Vitória da Conquista/BA, Brasil \\ ${ }^{3}$ Departamento de Engenharia Agrícola e Solos, Universidade Estadual do Sudoeste da Bahia - UESB, Vitória da \\ Conquista/BA, Brasil
}

\begin{abstract}
The present study was carried out with the objective of evaluating the field performance of six Eucalyptus clones, using seed-produced Eucalyptus urophylla as a reference. The experiment was conducted in the city of Vitória da Conquista, Bahia, Brazil. The plants were monitored monthly with diameter at ground level and height measurements taken up to nine months after planting. Diameter at breast height (DBH) and height measurements, as well as the biomass of all tree components and stem volumes were obtained 12 months after planting. VM058 and I-144 were the only clones that showed survival rates below $70 \%$. Nevertheless, up to the age of 12 months and similar to the seed-produced E. urophylla, the VM058 clone was the genetic material that presented the most satisfactory production given the edaphoclimatic conditions of Vitória da Conquista, Bahia, Brazil.
\end{abstract}

Keywords: biomass, productive potential, volume. 


\section{INTRODUCTION}

Faced with the growing demand for forest-based products, there has been an expansion of planted forest area in Brazil, which currently corresponds to about 7.8 million hectares (IBÁ, 2016). Eucalyptus are among the most frequently used forest species, which are distributed throughout the different regions of the country as a result of their good adaptability to diverse climate and soil conditions, as well as rapid growth.

In the state of Bahia, the areas planted with Eucalyptus totaled 614 thousand hectares in 2015 (IBÁ, 2016). These areas have expanded to the semiarid region of the state and particularly in the Southwest region, where the distribution and quantity of rainfall are factors that limit productivity and even survival of the species (Fernandes et al., 2013).

The selection of species tolerant to drought is of fundamental importance for the success of forestry activities, considering that plant growth and development are affected by biotic and abiotic factors, such as temperature and soil water content (Fernandes, 2012).

In this sense, genetic improvement programs carried out through techniques such as cloning have contributed considerably to the success of forestry enterprises in Brazil. By using these techniques, forest species are selected over time, thereby obtaining more productive genotypes that are better adapted to different edaphoclimatic conditions and with greater resistance to biotic and abiotic stresses (Studart-Guimarães et al., 2003). As a consequence, a progressive increase in the area of clonal forest plantations under the most varied environmental conditions of the Brazilian territory can be observed (Xavier \& Silva, 2010).

Forest genetic improvement seeks to achieve high production levels in terms of volume and biomass, guaranteeing wood quality, especially with regard to resistance to diseases, pests and abiotic damage (Assis et al., 1993; Castaneda et al., 2012). In order to achieve this goal and prior to recommendation and cultivation for commercial use, the clones must be field tested and evaluated in different environments (Magalhães, 2013). This prior evaluation is essential to understand the adaptive and productive capacity of the clones.

Although there is ample information about the adaptation and productivity of eucalyptus clones in different regions of Brazil, relevant studies for the Southwest of the state of Bahia are still scarce. To date, results for planted material has been collected from in nearby locations, such as in the Northeast of Minas Gerais.

Therefore, the present study was conducted to evaluate the field performance of six eucalyptus clones using Eucalyptus urophylla produced from seed, traditionally used in the study region as a control.

\section{MATERIAL AND METHODS}

\subsection{Characterization of the area}

The experiment was carried out at Baixão farm (geographical coordinates: $14^{\circ} 49^{\prime} \mathrm{S}$ and $40^{\circ} 59^{\prime} \mathrm{W}$ ), located in the district of Pradoso, belonging to the municipality of Vitória da Conquista, Bahia, Brazil, which is located on the Planalto da Conquista, at altitudes ranging from 857 to $1,000 \mathrm{~m}$. The region is flat with a slightly rippled relief and has a tropical altitude climate (Cwb) according to Köppen's classification, with annual average temperature of $21^{\circ} \mathrm{C}$ and annual precipitation of approximately $700 \mathrm{~mm}$. The soil of the studied area has a clayey texture and belongs to the Dystrophic Yellow Latosol class (Santos et al., 2006). Table 1 shows the chemical and granulometric characterization of this soil at depths of $0-20$ and $20-40 \mathrm{~cm}$.

Table 1. Chemical and granulometric characterization of this soil at depths of $0-20$ and $20-40 \mathrm{~cm}$.

\begin{tabular}{|ccc|}
\hline Parameters & $\mathbf{0 - 2 0}$ & $\mathbf{2 0 - 4 0}$ \\
\hline $\mathrm{pH}\left(\mathrm{H}_{2} \mathrm{O}\right)^{(1)}$ & 4.4 & 4.4 \\
$\mathrm{P}\left(\mathrm{mg} \mathrm{dm}^{-3}\right)$ & 2 & 1 \\
$\mathrm{~K}\left(\mathrm{cmolcdm}^{-3}\right)$ & 0.13 & 0.08 \\
$\mathrm{Ca}\left(\mathrm{cmolcdm}^{-3}\right)$ & 0.6 & 0.3 \\
\hline $\mathrm{Mg}\left(\mathrm{cmolc} \mathrm{dm}^{-3}\right)$ & 0.5 & 0.2 \\
\hline $\mathrm{Al}\left(\mathrm{cmolcdm}^{-3}\right)$ & 1.2 & 1.3 \\
\hline $\mathrm{H}\left(\mathrm{cmolcdm}^{-3}\right)$ & 4.8 & 4 \\
\hline $\mathrm{Na}\left(\mathrm{cmolcdm}^{-3}\right)$ & 0 & 0.06 \\
\hline $\mathrm{S} . \mathrm{B}\left(\mathrm{cmolcdm}^{-3}\right)$ & 1.2 & 0.6 \\
\hline $\mathrm{t}\left(\mathrm{cmolcdm}^{-3}\right)$ & 2.4 & 1.9 \\
\hline $\mathrm{T}\left(\mathrm{cmolcdm}^{-3}\right)$ & 7.2 & 5.9 \\
\hline $\mathrm{V}(\%)$ & 17 & 11 \\
\hline m $(\%)$ & 49 & 67 \\
\hline Sand $\left(\mathrm{g} \mathrm{kg}^{-1}\right)$ & 630 & 630 \\
\hline Silt $\left(\mathrm{g} \mathrm{kg}^{-1}\right)$ & 20 & 30 \\
\hline Clay $\left(\mathrm{g} \mathrm{kg}^{-1}\right)$ & 350 & 340 \\
\hline
\end{tabular}

${ }^{(1)}$ Analyses carried out according to EMBRAPA (1979): $\mathrm{pH}$ (water); $\mathrm{P}$ and $\mathrm{K}$ extractable by Mehlich $^{-1}$; $\mathrm{Ca}, \mathrm{Mg}$ and $\mathrm{Al}$ exchangeable for $\mathrm{KCl} 1 \mathrm{~mol} \mathrm{~L}-{ }^{1}$ and organic matter (OM) by oxidation with $\mathrm{Na}_{2} \mathrm{Cr}_{2} \mathrm{O}_{7} 4 \mathrm{~N}$. Samples composed of 10 simple samples collected in the experimental area were used. 
Table 2. Hybrid clones of Eucalyptus used in the experiment.

\begin{tabular}{cc|}
\hline Clones & Species \\
\hline $\mathrm{I}-144$ & Eucalyptus urophylla \\
1355 & E. urophylla $\mathrm{x}$ E. grandis \\
\hline 1404 & Eucalyptus urophylla \\
1296 & E. urophylla $\mathrm{x}$ E. grandis \\
1249 & E.urophylla $\mathrm{x}$ E. grandis \\
\hline VM058 & E. camaldulensis $\mathrm{x}$ E. tereticornis \\
\hline
\end{tabular}

Seedlings of six eucalyptus clone hybrids were used as described in Table 2, using seedlings of Eucalyptus urophylla species produced from seed as a reference, since this is the most commonly cultivated species in the study region.

The experiment was carried out in a degraded area containing secondary vegetation at an early stage after crawler tractor cleaning and soil preparation with plowing, subsoiling in the planting lines at $50 \mathrm{~cm}$ of depth, and fertilization in the pits (300 grams of commercial fertilizer Basifós Forest 2, which contains $\mathrm{N}, \mathrm{P}_{2} \mathrm{O}_{5}, \mathrm{~K}_{2} \mathrm{O}, \mathrm{Ca}, \mathrm{S}, \mathrm{Mg}, \mathrm{Zn}, \mathrm{Mn}, \mathrm{Cu}$ and $\mathrm{Bin}$ in its composition). Initial ant control (before and after planting) was carried out using granulated formicide baits (Fortex), which were applied throughout the experimental and adjacent areas. The use of powdered commercial formicide was adopted for maintenance control.

Planting was done manually in June 2013 with the use of hydrogel, according to a $3 \mathrm{~m} \times 4 \mathrm{~m}$ spacing. A randomized block experimental design (RBD) was adopted with seven treatments and three replications, totaling 21 plots. Each experimental plot was composed of 3 plant lines containing 17 plants each, with the 13 middle plants of the intermediate line considered the useful plot.

Because the experiment implementation month corresponded to a dry period in the region, manual watering of seedlings in the field was adopted (three times per week, with approximately three liters of water per pit) up to 60 days after planting.

Maintenance in the experimental area was carried out at two months with crowning around the seedlings, and at six months after planting by mowing the lines and between the lines for weed control.

\subsection{Analyzed variables}

Diameter at ground level and plant height measurements were taken monthly using a digital caliper and a graduated ruler, respectively, until the ninth month after planting. Determination of the survival percentage was evaluated 90 days after planting.

Diameter at breast height (DBH) and total height of all trees in the experimental plots were measured 12 months after planting. In this step, the diameter was measured using a mechanical bevel gauge and height was measured using a Haglof ${ }^{\circledR}$ hypsometer.

The biomass of the tree components (leaves, branches, stem and roots) and the volume of the stems were also determined twelve months after planting. To do so, 21 trees (one from each experimental plot) were randomly selected and felled. The biomass quantification was performed by the simple separation method (Sanquetta et al., 2004). Each sample tree was separated into leaf, branch, stem and root compartments, which were weighed on a mechanical scale ( $150 \mathrm{~kg}$ capacity and $50 \mathrm{~g}$ precision). In order to collect the roots, one cubic meter trenches were dug with the stem of the tree positioned in the central part, and the existing material in this volume was collected. After weighing, samples were taken from each compartment (which were then taken to the laboratory), weighed on a precision scale $(0.01 \mathrm{~g})$, dried in a forced air circulation oven $\left(\right.$ at $65^{\circ} \mathrm{C}$ until stabilization of dry mass) and weighed again.

Volume was determined out by rigorous sampling using the Smalian method. Diameters with bark were measured in the positions $0.05 \mathrm{~m}, 0.3 \mathrm{~m}, 0.7 \mathrm{~m}$ and $1.3 \mathrm{~m}$ from the soil level in each stem. From then on, the sections were measured at intervals of $1 \mathrm{~m}$, and the tip length was also obtained after measuring the last section. Diameter and stem height measurements were obtained with the aid of a bevel gauge and tape measure, respectively. The total volume of each stem was obtained by the sum of the volume of the sections plus the tip volume.

\subsection{Statistical analysis}

In order to evaluate the growth rate of the seedlings in the field, diameter at ground level and plant height data up to nine months after planting was analyzed by regression using the statistical program $S A E G^{\circledR}$ v.9.1.

Diameter and height data at nine months, and biomass, volume, $\mathrm{DBH}$ and height data at twelve months were submitted to analysis of variance, adopting the $\mathrm{F}$ test and Tukey test both at $5 \%$ significance for comparison of means, and using the statistical software SISVAR ${ }^{\circledR}$ v.5.3 (Ferreira, 2010). 


\section{RESULTS AND DISCUSSION}

The best survival results (about 90\%) were achieved by clones 1404, 1296 and 1249, as well as by E. urophylla (Table 3). By contrast, the lowest indices were verified for clones I-144 (56\%) and VM058 (67\%). Survival values between 50 and $95 \%$ were observed in several studies with different eucalyptus species in the Northeast (Gadelha et al., 2012, 2015; Lopes et al., 2014) and in other regions of Brazil (Quiqui et al., 2001; Magalhães et al., 2007; Mendonça et al., 2008; Queiroz et al., 2009; Vilas Bôas et al., 2009; Santos et. al., 2014). A survival performance of over $75 \%$ is desirable so that there is no significant damage to the establishment of forest populations (Santos et al., 2014), so much so that this value can be used as a reference for the indication of species. Therefore, among the evaluated clones, only I-144 and VM058 would not be considered promising for the edaphoclimatic conditions of the study

Table 3. Mean survival index values of E. urophylla seedlings and six hybrid clones 90 days after planting.

\begin{tabular}{|cc|}
\hline Treatment & Survival (\%) \\
\hline E. urophylla & $\mathbf{9 2}$ \\
\hline I-144 & $\mathbf{5 6}$ \\
1355 & $\mathbf{7 7}$ \\
1404 & $\mathbf{9 2}$ \\
1296 & $\mathbf{9 0}$ \\
1249 & $\mathbf{8 5}$ \\
\hline VM058 & $\mathbf{6 7}$ \\
\hline
\end{tabular}

region. However, in addition to survival rates, the selection and recommendation of adapted genetic material should also take into account other aspects such as the growth and productivity of variables of interest (Azevedo et al., 2015; Frigotto, 2016).

The mathematical model that best explained the growth rate of clones in the field for diameter at ground level and (plant) height for all genetic materials evaluated as a function of age was the quadratic model, represented by the equation: $Y=\beta_{0}+\beta_{1} \mathrm{~T}+\beta_{0} \mathrm{~T}^{2}$. The regression equations adjusted for both diameter and height are presented in Table 4.

The behavior of the curves adjusted for diameter as a function of time showed a higher growth rate of Eucalyptus urophylla (Figure 1), which presented a regular and progressive increase in the slope of its curve. However, it is noted that this rhythm could have been surpassed by clone VM058 if the growth assessment was carried out over a period of more than nine months. It is also possible to observe that the curves of the other clones generally showed a similar growth pattern, with the greatest differentiation in the curve of clone 1355, which presented smaller increases over time. According to Sette et al. (2012), the diameter growth curve trend commonly observed in eucalyptus plantations is characterized by high growth rates in the initial period, which stabilize over time in response to increased competition for growth factors.

No significant differences were found when comparing the diameter at ground level between treatments up to

Table 4. Equations adjusted for height and diameter of seed-produced E. Urophylla plants and six hybrid eucalyptus clones nine months after planting.

\begin{tabular}{|c|c|c|c|}
\hline Treatment & Equation & $\mathrm{SE}^{(1)}$ & $\mathbf{R}^{2}$ \\
\hline \multirow{2}{*}{ E. urophylla } & $\mathrm{H}=0.2742-0.0004 \mathrm{~T}+0.00000376 \mathrm{~T}^{2}$ & 0.07 & $99.39^{*}$ \\
\hline & $\mathrm{D}=-0.0104+0.0091 \mathrm{~T}+0.00000365 \mathrm{~T}^{2}$ & 0.09 & $99.69^{*}$ \\
\hline \multirow{2}{*}{ I-144 } & $\mathrm{H}=0.4970-0.0053 \mathrm{~T}+0.00000461 \mathrm{~T}^{2}$ & 0.08 & $98.81^{\star}$ \\
\hline & $\mathrm{D}=0.2747-0.0012 \mathrm{~T}+0.00000598 \mathrm{~T}^{2}$ & 0.14 & $99.05^{*}$ \\
\hline \multirow{2}{*}{1355} & $\mathrm{H}=0.4533-0.0013 \mathrm{~T}+0.00000314 \mathrm{~T}^{2}$ & 0.07 & $98.88^{*}$ \\
\hline & $\mathrm{D}=-0.0870+0.0110 \mathrm{~T}+0.00000185 \mathrm{~T}^{2}$ & 0.26 & $96.56^{*}$ \\
\hline \multirow{2}{*}{1404} & $\mathrm{H}=0.3822-0.0033 \mathrm{~T}+0.00000389 \mathrm{~T}^{2}$ & 0.04 & $99.69^{*}$ \\
\hline & $\mathrm{D}=0.1252+0.0022 \mathrm{~T}+0.00000478 \mathrm{~T}^{2}$ & 0.12 & $99.21^{*}$ \\
\hline \multirow{2}{*}{1296} & $\mathrm{H}=0.4240-0.0012 \mathrm{~T}+0.00000310 \mathrm{~T}^{2}$ & 0.05 & $99.38^{*}$ \\
\hline & $\mathrm{D}=0.1725+0.0048 \mathrm{~T}+0.00000401 \mathrm{~T}^{2}$ & 0.09 & $99.58^{*}$ \\
\hline \multirow{2}{*}{1249} & $\mathrm{H}=0.3431-0.0013 \mathrm{~T}+0.00000323 \mathrm{~T}^{2}$ & 0.05 & $99.51^{\star}$ \\
\hline & $\mathrm{D}=0.0945+0.0037 \mathrm{~T}+0.00000506 \mathrm{~T}^{2}$ & 0.18 & $98.41^{*}$ \\
\hline \multirow{2}{*}{ VM058 } & $\mathrm{H}=0.3644-0.0026 \mathrm{~T}+0.00000460 \mathrm{~T}^{2}$ & 0.08 & $99.34^{*}$ \\
\hline & $\mathrm{D}=0.0804+0.0037 \mathrm{~T}+0.00000506 \mathrm{~T}^{2}$ & 0.06 & $99.82^{*}$ \\
\hline
\end{tabular}

(1) $\mathrm{SE}=$ Standard error of the estimate; $\mathrm{R}^{2}=$ Adjusted coefficient of determination; ${ }^{*} \mathrm{p}<0.0001$. 
nine months after planting (Table 5) until the third month. A lower performance of clone I-144 when compared to E. urophylla was observed from the fourth until the seventh month. Clone VM058 stood out nine months after planting in comparison with the other clones $(4.5 \mathrm{~cm})$, however it did not statistically differ from E.urophylla $(5.1 \mathrm{~cm})$ (Table 5). Plants with larger diameters have a greater chance of survival and establishment in the field

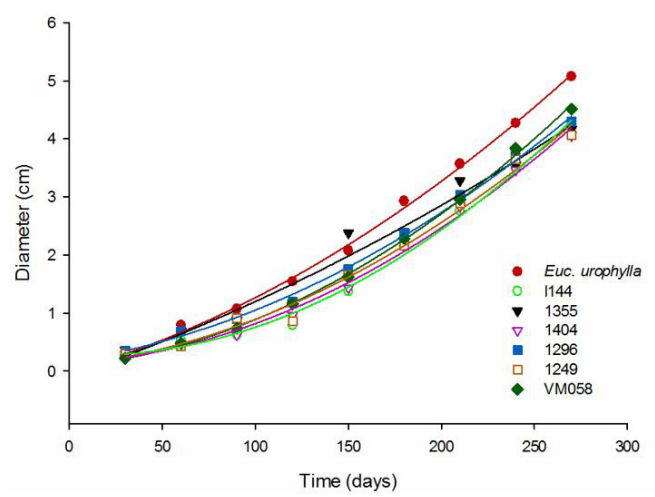

Figure 1. Growth curves of the diameter at ground level in seed-produced E. urophylla and six hybrid eucalyptus clones up to nine months after planting. given their greater capacity to form and grow new roots (Souza et al., 2006). Therefore, despite its low survival rate (less than 70\%), VM058 is the most adapted clone with the greatest development potential in the studied edaphoclimatic conditions.

The growth curves obtained for the height variable showed larger increments from the sixth month after planting (Figure 2), especially for clone VM058 and E.urophylla,

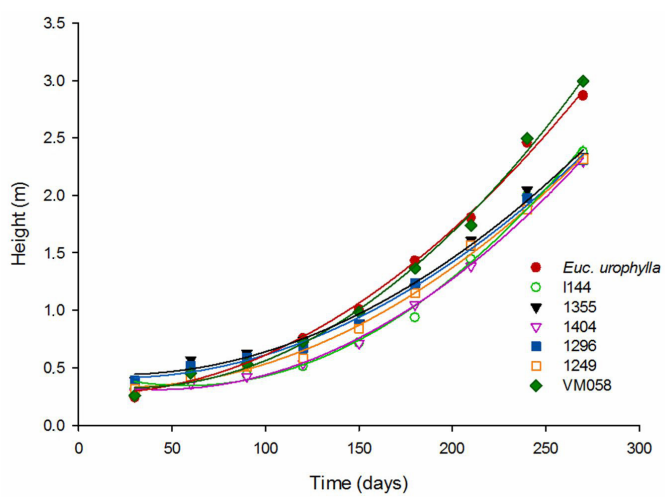

Figure 2. Growth curve of the (plant) height in seed-produced E. urophylla and six hybrid eucalyptus clones up to nine months after planting.

Table 5. Mean values of the diameter at ground level and (plant) height in seed-produced E. urophylla and six hybrid eucalyptus clones up to nine months after planting.

\begin{tabular}{|c|c|c|c|c|c|c|c|}
\hline \multirow{2}{*}{ Month } & \multicolumn{7}{|c|}{ Genetic material } \\
\hline & E. urophylla & I-144 & 1355 & 1404 & 1296 & 1249 & VM058 \\
\hline & \multicolumn{7}{|c|}{ DIAMETER $(\mathrm{cm})$} \\
\hline 1 & $0.26 \mathrm{a}^{(1)}$ & $0.30 \mathrm{a}$ & $0.36 \mathrm{a}$ & $0.30 \mathrm{a}$ & $0.35 \mathrm{a}$ & $0.30 \mathrm{a}$ & $0.22 \mathrm{a}$ \\
\hline 2 & $0.79 \mathrm{a}$ & $0.53 \mathrm{a}$ & $0.69 \mathrm{a}$ & $0.46 \mathrm{a}$ & $0.68 \mathrm{a}$ & $0.43 \mathrm{a}$ & $0.48 \mathrm{a}$ \\
\hline 3 & $1.07 \mathrm{a}$ & $0.62 \mathrm{a}$ & $0.87 \mathrm{a}$ & $0.75 \mathrm{a}$ & $0.90 \mathrm{a}$ & $0.65 \mathrm{a}$ & $0.74 \mathrm{a}$ \\
\hline 4 & $1.54 \mathrm{a}$ & $0.79 \mathrm{~b}$ & $1.17 \mathrm{ab}$ & $0.96 \mathrm{ab}$ & $1.19 \mathrm{ab}$ & $0.98 \mathrm{ab}$ & $1.15 \mathrm{ab}$ \\
\hline 5 & $2.07 \mathrm{a}$ & $1.37 \mathrm{~b}$ & $1.72 \mathrm{ab}$ & $1.43 \mathrm{ab}$ & $1.76 \mathrm{ab}$ & $1.65 \mathrm{ab}$ & $1.61 \mathrm{ab}$ \\
\hline 6 & $2.93 \mathrm{a}$ & $2.06 \mathrm{~b}$ & $2.38 \mathrm{ab}$ & $2.18 \mathrm{~b}$ & $2.39 \mathrm{ab}$ & $2.17 \mathrm{~b}$ & $2.28 \mathrm{~b}$ \\
\hline 7 & $3.57 \mathrm{a}$ & $2.76 \mathrm{~b}$ & $3.09 \mathrm{ab}$ & $2.83 \mathrm{~b}$ & $3.03 \mathrm{ab}$ & $2.89 \mathrm{~b}$ & $2.95 \mathrm{ab}$ \\
\hline 8 & $4.27 \mathrm{a}$ & $3.53 \mathrm{~b}$ & $3.55 \mathrm{~b}$ & $3.46 \mathrm{~b}$ & $3.70 \mathrm{ab}$ & $3.64 \mathrm{ab}$ & $3.84 \mathrm{ab}$ \\
\hline \multirow[t]{2}{*}{9} & $5.07 \mathrm{a}$ & $4.19 \mathrm{~b}$ & $4.16 \mathrm{~b}$ & $4.06 \mathrm{~b}$ & $4.29 \mathrm{~b}$ & $4.06 \mathrm{~b}$ & $4.51 \mathrm{ab}$ \\
\hline & \multicolumn{7}{|c|}{ HEIGHT (m) } \\
\hline 1 & $0.24 \mathrm{a}$ & $0.31 \mathrm{a}$ & $0.39 \mathrm{a}$ & $0.29 \mathrm{a}$ & $0.39 \mathrm{a}$ & $0.31 \mathrm{a}$ & $0.26 \mathrm{a}$ \\
\hline 2 & $0.47 \mathrm{a}$ & $0.43 \mathrm{a}$ & $0.57 \mathrm{a}$ & $0.36 \mathrm{a}$ & $0.52 \mathrm{a}$ & $0.42 \mathrm{a}$ & $0.45 \mathrm{a}$ \\
\hline 3 & $0.57 \mathrm{a}$ & $0.44 \mathrm{a}$ & $0.63 \mathrm{a}$ & $0.42 \mathrm{a}$ & $0.59 \mathrm{a}$ & $0.50 \mathrm{a}$ & $0.53 \mathrm{a}$ \\
\hline 4 & $0.75 \mathrm{a}$ & $0.51 \mathrm{a}$ & $0.74 \mathrm{a}$ & $0.54 \mathrm{a}$ & $0.67 \mathrm{a}$ & $0.58 \mathrm{a}$ & $0.73 \mathrm{a}$ \\
\hline 5 & $1.00 \mathrm{a}$ & $0.71 \mathrm{a}$ & $0.89 a$ & $0.71 \mathrm{a}$ & $0.88 \mathrm{a}$ & $0.84 \mathrm{a}$ & $0.98 \mathrm{a}$ \\
\hline 6 & $1.43 \mathrm{a}$ & $0.94 \mathrm{c}$ & $1.20 \mathrm{abc}$ & $1.05 \mathrm{bc}$ & $1.23 \mathrm{abc}$ & $1.15 \mathrm{abc}$ & $1.37 \mathrm{ab}$ \\
\hline 7 & $1.80 \mathrm{a}$ & $1.44 \mathrm{bc}$ & $1.61 \mathrm{abc}$ & $1.38 \mathrm{c}$ & $1.56 \mathrm{abc}$ & $1.57 \mathrm{abc}$ & $1.74 \mathrm{ab}$ \\
\hline 8 & $2.46 \mathrm{a}$ & $1.99 \mathrm{~b}$ & $2.05 \mathrm{~b}$ & $1.88 \mathrm{~b}$ & $1.97 \mathrm{~b}$ & $1.88 \mathrm{~b}$ & $2.50 \mathrm{a}$ \\
\hline 9 & $2.87 \mathrm{a}$ & $2.38 \mathrm{~b}$ & $2.33 \mathrm{~b}$ & $2.30 \mathrm{~b}$ & $2.30 \mathrm{~b}$ & $2.32 \mathrm{~b}$ & $2.99 \mathrm{a}$ \\
\hline
\end{tabular}

(1) Means followed by the same letters in the line do not differ by Tukey test at $5 \%$ probability. 
which had the highest growth rate. However, at the end of the nine months, clone VM058 showed a tendency to stand out in height growth, not only in relation to the other clones evaluated, but also in relation to E. urophylla.

No variations were observed between treatments for the height variable up to the fifth month of evaluation (Table 5). From the sixth month on, E. urophylla and the clone VM058 showed the strongest height performances (Figure 2), although a significant difference in relation to other genetic materials was only observed for the last two months of evaluation (Table 5). This result suggests that similar to E. urophylla, the VM058 clone presented a greater capacity for competition and adaptation to the local conditions in relation to the other evaluated clones. According to Sturion \& Bellote (2000), plants that present greater height in the initial phase of establishment in the field have a greater capacity to dominate the competition with the spontaneous vegetation, minimizing the need for cultural treatment, and therefore, reducing of the plantation costs. For Macedo et al. (2016), variations in mean height of forest species show different genetic capacities to exploit the productive potential of the introduction "habitat" and are usually related to their phenotypic plasticity.

No differences were observed between treatments for height and $\mathrm{DBH}$ variables at 12 months after planting, which presented mean values of $3.5 \mathrm{~m}$ and $8 \mathrm{~cm}$, respectively. These results are in agreement with those found by Correia et al. (2012), who found a statistical difference in the diameter and height values at 90 and 180 days of age, but no significant variation at 365 days after planting clonal eucalyptus seedlings. Higher results for height were observed by
Figueiredo et al. (2011), who found an average value of 5.9 min evaluating Eucalyptus grandis $\mathrm{x}$ E. urophylla clones up to 12 months after planting in the North of Minas Gerais.

The stem volume variable presented higher results for clone VM058 and for E. Urophylla (mean of $0.0052 \mathrm{~m}^{3} /$ tree) in relation to clones 1355 , 1296 and 1249 (mean of $0.0025 \mathrm{~m}^{3}$ ), which represents a difference of more than $50 \%$. This corroborates with previously discussed results indicating greater adaptive capacity of clone VM058 and E. urophylla, which was reflected in the higher volume response. This result may be related to characteristics of the genetic material, such as greater efficiency in stomatal control and greater size or expansion of the root system (Leles et al., 1998), allowing more satisfactory growth of this clone in an environment that presents a considerable water deficit.

Differences were also identified between the clones in terms of stem, root and total biomass production (Table 6). The highest stem yields were observed in E. urophylla, which resembled clones VM058, 1404 and I-144, being in agreement with the greater volume development of these first two genetic materials (Table 6). Regarding root biomass, E. urophylla also presented higher performance, although without variation in relation to clones VM058 and 1355. The total biomass production of the clones followed the stem and root biomass pattern; however, in this case, E. urophylla resembled most of the evaluated clones, only being distinguished from clone 1249 which presented a lower production. In general, the tree biomass results obtained showed that none of the tested clones presented performance superior to E. urophylla, although some of them, especially clone VM058, presented biomass production equal to

Table 6. Biomass production, height, DBH and volume in seed-produced E. urophylla and six hybrid eucalyptus clones at twelve months after planting in the field.

\begin{tabular}{|c|c|c|c|c|c|c|c|c|}
\hline \multirow{2}{*}{$\begin{array}{l}\text { Genetic } \\
\text { material }\end{array}$} & \multicolumn{5}{|c|}{ Biomass (kg tree $\left.{ }^{-1}\right)$} & \multirow{2}{*}{$\begin{array}{c}\mathrm{H} \\
(\mathrm{m})\end{array}$} & \multirow{2}{*}{$\begin{array}{l}\text { DBH } \\
(\mathrm{cm})\end{array}$} & \multirow{2}{*}{$\begin{array}{c}\text { Volume } \\
\left(\mathrm{m}^{3}\right)\end{array}$} \\
\hline & Leaves & Branches & Stem & Roots & Total & & & \\
\hline E. urophylla & $3.8572 \mathrm{a}^{(1)}$ & $1.9895 \mathrm{a}$ & $3.8906 \mathrm{a}$ & $2.4349 \mathrm{a}$ & $12.1723 \mathrm{a}$ & $3.6133 \mathrm{a}$ & $3.1933 \mathrm{a}$ & $0.0053 \mathrm{a}$ \\
\hline I-144 & $2.8324 \mathrm{a}$ & $1.4081 \mathrm{a}$ & $1.4618 \mathrm{ab}$ & $1.2176 \mathrm{~b}$ & $6.9199 \mathrm{ab}$ & $3.1567 \mathrm{a}$ & $2.9433 \mathrm{a}$ & $0.0034 \mathrm{ab}$ \\
\hline 1355 & $2.9926 \mathrm{a}$ & $2.2793 \mathrm{a}$ & $1.3521 \mathrm{~b}$ & $1.6112 \mathrm{ab}$ & $8.2352 \mathrm{ab}$ & $3.2633 \mathrm{a}$ & $2.6000 \mathrm{a}$ & $0.0023 \mathrm{~b}$ \\
\hline 1404 & $2.6803 \mathrm{a}$ & $1.3661 \mathrm{a}$ & $2.1105 \mathrm{ab}$ & $1.1104 \mathrm{~b}$ & $7.2673 \mathrm{ab}$ & $3.4367 \mathrm{a}$ & $2.9433 \mathrm{a}$ & $0.0042 \mathrm{ab}$ \\
\hline 1296 & $3.2750 \mathrm{a}$ & $2.2654 \mathrm{a}$ & $1.3297 \mathrm{~b}$ & $1.2069 \mathrm{~b}$ & $8.0770 \mathrm{ab}$ & $3.7733 \mathrm{a}$ & $2.8200 \mathrm{a}$ & $0.0028 \mathrm{~b}$ \\
\hline 1249 & $2.2942 \mathrm{a}$ & $0.9049 \mathrm{a}$ & $1.0776 \mathrm{~b}$ & $0.9126 \mathrm{~b}$ & $5.1894 \mathrm{~b}$ & $3.3267 \mathrm{a}$ & $2.3933 \mathrm{a}$ & $0.0024 \mathrm{~b}$ \\
\hline VM058 & $2.4126 \mathrm{a}$ & $1.6363 \mathrm{a}$ & $2.8608 \mathrm{ab}$ & $1.4413 \mathrm{ab}$ & $8.3510 \mathrm{ab}$ & $3.7167 \mathrm{a}$ & $3.0533 \mathrm{a}$ & $0.0052 \mathrm{a}$ \\
\hline
\end{tabular}

(1) Means followed by the same letter in the line do not differ by the Tukey test at $5 \%$ significance. $\mathrm{H}=$ Height; DBH = Diameter at breast height; Volume $=$ Stem volume . 
seed-produced Eucalyptus. This indicates a similarity in their productive potentials and suggests that both can be recommended for planting in the study region.

Several studies have found differences in the biomass production of Eucalyptus clones (Lima et al., 2005; Vellini et al., 2008; Pinto et al., 2011). Such differences can be attributed to variations in the efficiency of use and conversion of nutrients to biomass by different species (Pinto et al., 2011), which according to Furtini (1994), should be considered in order for the genotype $\mathrm{x}$ environment interaction data to be used to effectively select species.

\section{CONCLUSION}

Eucalyptus clones differ in terms of survival, diameter and height growth and volume and biomass production. VM058 and I-144 were the only clones that showed survival rates below 70\%. Despite this, clone VM058 as well as the seed-produced E. urophylla were the genetic materials that presented the most satisfactory production up to 12 months given the edaphoclimatic conditions of Vitória da Conquista, Bahia.

\section{SUBMISSION STATUS}

Received: 29 nov., 2016

Accepted: 22 june, 2017

\section{CORRESPONDENCE TO}

\section{Patrícia Anjos Bittencourt Barreto-Garcia}

Departamento de Engenharia Agrícola e Solos, Universidade Estadual do Sudoeste da Bahia UESB, Estrada do Bem Querer, Km 04, CP 95 , CEP 45031-300, Vitória da Conquista, BA, Brasil e-mail: patriciabarreto@uesb.edu.br

\section{REFERENCES}

Assis TF, Bauer JFS, Tafarel G. Sintetização de híbridos de Eucalyptus por cruzamentos controlados. Ciência Florestal 1993; 3(1): 161-170. http://dx.doi.org/10.5902/19805098291.

Azevedo LPA, Costa RB, Martinez DT, Tsukamoto AA Fo, Brondani GE, Baretta MC et al. Seleção genética em progênies de Eucalyptus camaldulensis em área de cerrado matogrossense. Ciência Rural 2015; 45(11): 2001-2006. http://dx.doi.org/10.1590/0103-8478cr20131557.
Castaneda DAF, Paz LC, Ribeiro GT, Santos MJC. Avaliação de crescimento de um plantio experimental com 3 clones de eucalipto (Eucalyptus) em Sergipe. Scientia Plena 2012; 8(4): 1

Correia ACG, Santana RC, Oliveira MLR, Titon M, Ataíde GM, Leite FP. Volume de substrato e idade: influência no desempenho de mudas clonais de eucalipto após replantio. Cerne 2012; 19(2): 185-191. http://dx.doi.org/10.1590/ S0104-77602013000200002.

Empresa Brasileira de Pesquisa Agropecuária - EMBRAPA. Serviço Nacional de Levantamento e Conservação de Solos. Manual de métodos de análise de solo. Rio de Janeiro; 1979.

Fernandes ET. Fotossíntese e crescimento inicial de clones de eucalipto sob diferentes regimeshídricos [dissertação]. Vitória da Conquista: Universidade Estadual do Sudoeste da Bahia; 2012.

Fernandes ET, Cairo PAR, Morais JLC. Crescimento de clones de eucalipto sob deficiência hídrica. Enciclopédia Biosfera 2013; 9(17): 868-875.

Ferreira DF. SISVAR: sistema de análise de variância. Versão 5.3. Lavras: UFLA; 2010.

Figueiredo FAMMA, Carneiro JGA, Penchel RM, Barroso DG, Daher RF. Efeito das variações biométricas de mudas clonais de eucalipto sobre o crescimento no campo. Revista Árvore 2011; 35(1):1-11. http://dx.doi.org/10.1590/S010067622011000100001 .

Frigotto T. Seleção de espécies/procedências e propagação vegetativa de Eucalyptus spp. na região norte de Santa Catarina [dissertação]. Lages: Universidade do Estado de Santa Catarina; 2016.

Furtini, AE No. Eficiência nutricional, cinética deabsorção e frações fosfatadas em Eucalyptus ssp. [tese]. Viçosa: Universidade Federal de Viçosa; 1994.

Gadelha FHL, Silva JAA, Silva JAA, Ferreira RLC, Ferreira RLC, Melo IV et al. Rendimento volumétrico e energético de clones de híbridos de Eucalyptus spp. no Polo Gesseiro do Araripe-PE. Ciência Florestal 2012; 22(2): 331-341. http://dx.doi.org/10.5902/198050985740.

Gadelha FHL, Silva JAA, Ferreira RLC, Melo IV, Santos RC, Tavares JA. Produtividade de clones de eucaliptos em diferentes sistemas de manejo para fins energéticos. Pesquisa Florestal Brasileira 2015; 35(83): 263-270. http:// dx.doi.org/10.4336/2015.pfb.35.83.827.

Indústria Brasileira de Árvores - IBÁ. Relatório anual da IBÁ 2016, ano base 2015. Brasília; 2016.

Leles PSS, Reis GG, Reis NGF, Morais EJ. Relações hídricas e crescimento de árvores de Eucalyptus camaldulensis e Eucalyptus pellita sob diferentes espaçamentos na região de cerrado. Revista Árvore 1998; 22(1): 41-50.

Lima AMN, Neves JCL, Silva IR, Leite FP. Cinética de absorção e eficiência nutricional de K, Ca e Mg em plantas jovens de quatro clones de eucalipto. Revista Brasileira 
de Ciência do Solo 2005; 29(6): 903-909. http://dx.doi. org/10.1590/S0100-06832005000600008.

Lopes ED, Amaral CLF, Novaes AB. Desempenho no campo de mudas de Eucalyptus urophylla, Eucalyptus camaldulensis e Corymbia citriodora produzidas em diferentes recipientes. Floresta 2014; 44(4): 589-596. http://dx.doi.org/10.5380/rf.v44i4.26480.

Macedo RLG, Bezerra RG, Venturin N, Vale RSD, Oliveira TD. Desempenho silvicultural de clones de eucalipto e características agronômicas de milho cultivados em sistema silviagrícola. Revista Árvore 2016; 30(5): 701-709. http://dx.doi.org/10.1590/S0100-67622006000500003.

Magalhães GC. Desempenho de clones de eucalipto nas condições edafoclimáticas de Vitória da Conquista - BA [dissertação]. Vitória da Conquista: Universidade Estadual do Sudoeste da Bahia; 2013.

Magalhães WM, Macedo RLG, Venturin N, Higashikawa EM, Yoshitani M Jr. Desempenho silvicultural de clones e espécies/procedências de Eucalyptus na região noroeste de Minas Gerais. Cerne 2007; 13(4): 368-375.

Mendonça AVR, Carneiro JGA, Barroso DG, Santiago AR, Freitas TAS, Souza JS. Desempenho de quatro de Eucalyptus spp em plantios puros e consorciados com sabiá (Mimosa caesalpiniaefolia Benth) em cava de extração de argila. Revista Árvore 2008; 32(3): 395-405. http://dx.doi. org/10.1590/S0100-67622008000300002.

Pinto SIC, Furtini AE No, Neves JCL, Faquin V, Moretti BS. Eficiência nutricional de clones de eucalipto na fase de mudas cultivados em solução nutritiva. Revista Brasileira de Ciência do Solo 2011; 35(2): 523-533. http://dx.doi. org/10.1590/S0100-06832011000200021.

Queiroz MM, Leles PSS, Oliveira SN No, Ferreira MA. Comportamento de materiais genéticos de eucalipto em Paty do Alferes, RJ. Floresta e Ambiente 2009; 16(1): 1-10.

Quiqui EM, Martins SS, Shimizu JY. Avaliação de espécies e procedências de Eucalyptus para o Noroeste do estado do Paraná. Acta Scientiarum 2001; 23(5): 1173-1177.

Sanquetta CRR, Corte APD, Balbinot R, Zilliotto MAB. Proposta metodológica para quantificação e monitoramento do carbono estocado em florestas plantadas. In: Sanquetta
CR, Zilliotto MAB. Mercado de carbono: mercado e ciência. Curitiba: UFPR; 2004. p. 120-150.

Santos AFA, Martinez DT, Caldeira SF, Rossi AS, Barbosa J Fo. Desempenho silvicultural de 21 clones do gênero Eucalyptus no sul do estado de Mato Grosso. In: Malinovski JR, Malinovski RA, Malinovski RA, Massetto GC, editores. Anais do $3^{\circ}$ Encontro Brasileiro de Silvicultura; 2014; Campinas. Curitiba: EMBRAPA; 2014. 308 p.

Santos HG, Jacomine PKT, Anjos LHC, Oliveira VA, Oliveira JB, Coelho MR. Sistema brasileiro de classificação de solos. 2. ed. Rio de Janeiro: Embrapa Solos; 2006.

Sette CR Jr, Tomazello M Fo, Lousada JL, Laclau JP. Sazonalidade do incremento em diâmetro do tronco de árvores de Eucalyptus grandis pelo uso de dendrômetros. Ciência Florestal 2012; 22(4): 763-775.

Souza GVR, Ferreira LR, Sediyama CS, Silva CM, Tuffi Santos LD, Viana RG. Exsudato radicular de imazapyr aplicado sobre mudas de diferentes clones de eucalipto. Planta Daninha 2006; 24(1): 141-147. http://dx.doi. org/10.1590/S0100-83582006000100018.

Studart-Guimarães C, Lacorte C, Brasileiro ACM. Transformação genética em espécies florestais. Ciência Florestal, Santa Maria 2003; 13(1): 167-178.

Sturion JA, Bellote AFJ. Implantação de povoamentos florestais com espécies de rápido crescimento. In: Galvão APM. Reflorestamento de propriedades rurais para fins produtivos e ambientais. Brasília: Embrapa Comunicação para Transferência de Tecnologia; 2000. p. 209-219. (vol. 1 , no. 1).

Vellini ALTT, Paula NF, Alves PLCA, Pavani LC, Bonine CAV, Scarpinati EA et al. Respostas fisiológicas de diferentes clones de eucalipto sob diferentes regimes de irrigação. Revista Árvore 2008; 32(4): 651-663. http:// dx.doi.org/10.1590/S0100-67622008000400006.

Vilas Bôas O, Max JCM, Melo ACG. Crescimento comparativo de espécies de Eucalyptus e Corymbia no município de Marília - SP. Revista do Instuto Florestal 2009; 21(1): 63-72.

Xavier A, Silva RL. Evolução da silvicultura clonal de Eucalyptus no Brasil. Agronomia Costarricense 2010; 34(1): 93-98. 